\title{
Detection of virulence factors of Pseudomonas aeruginosa in different animals by using bacteriological and molecular methods
}

\author{
B.S. Noomi \\ Collage of Veterinary Medicine, Tikrit University, Tikrit, Iraq \\ Email: Vetbashar1981@gmail.com, Tel: 07716184477
}

(Received January 30, 2018; Accepted March 15, 2018)

\begin{abstract}
The aim of this study was to detect the presence of virulence factors of Pseudomonas aeruginosa in different animals. For this purpose 120 samples were collected and examined to detect fourteen virulence factors by using biochemical and molecular methods. The results showed that the highest isolation rate was recorded in doges $(29.6 \%)$ among studied animals, and highest isolation rate was recorded in milk samples $(26.8 \%)$ among the studied samples. The virulence factors were detected in different ratio, and highest of them were capsule detected in $50 \%$ from skin isolates, amylase enzyme detected in $28.5 \%$ from milk isolates, hemolysin enzyme detected in $75 \%$ from wound isolates, protease detected in $100 \%$ from skin isolates, phospholipase enzyme detected in $56.1 \%$ from milk isolates, urease enzyme detected in $50 \%$ from skin isolates, gelatin liquefaction detected in $100 \%$ from skin and ear isolates, $\beta$-lactamase production detected in $100 \%$ from skin and wound isolates, pigments production detected in 100\% from skin and ear isolates, oprI, oprL and exoT detected in $100 \%$ from skin and wound isolates, exoS detected in $100 \%$ and $85.7 \%$ from skin and milk isolates respectively. We conclude from his study that the dogs are more sensitive in compare with studied animal, while the milk sample is more susceptible to contamination by Pseudomonas aeruginosa. Regarding the virulence factors we noticed that the appearance of it basis on infection state.
\end{abstract}

Keywords: Pseudomonas aeruginosa, virulence factors, molecular methods Available online at http://www.vetmedmosul.com

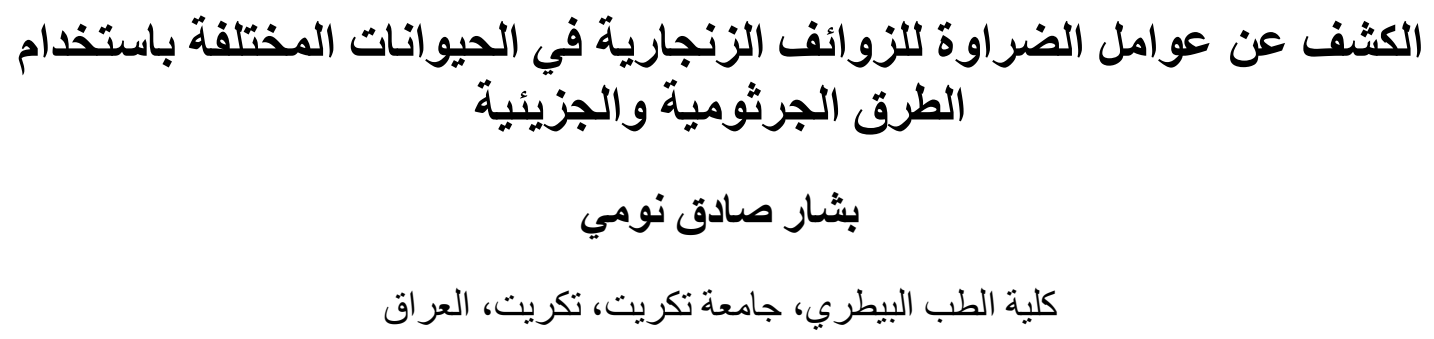

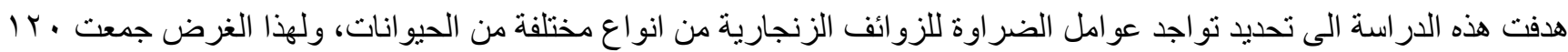

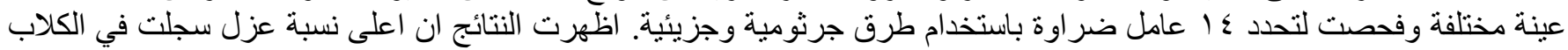

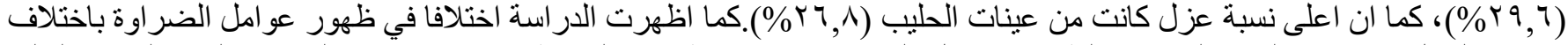

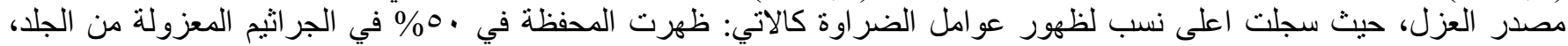

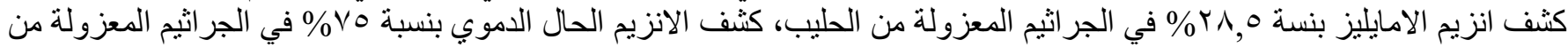

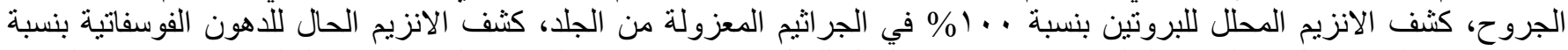

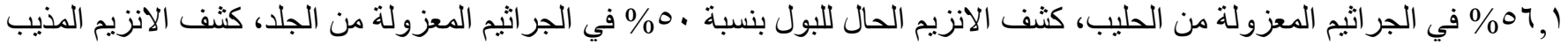

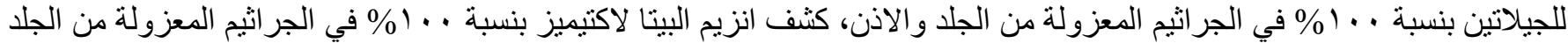

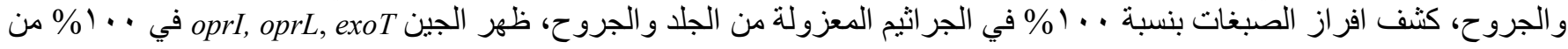




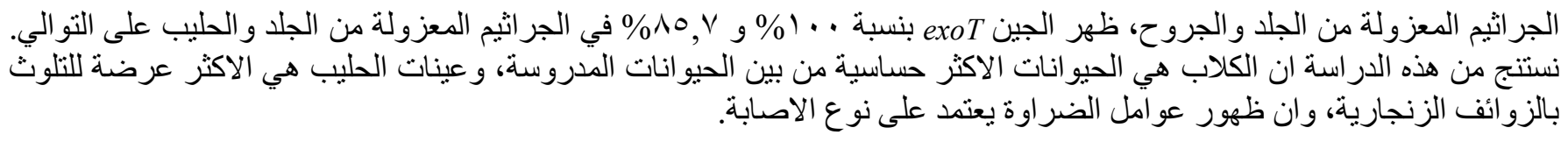

\section{Introduction}

Pseudomonas aeruginosa is a Gram negative bacteria, non spore forming, obligate aerobes, motile by one or more polar flagella, most isolates are oxidase and catalase positive (1,2). Pyocyanin, pyoverdin, fluorescence, pyorubin and pyomelanin are a pigments produced by Pseudomonas spp. (3).

Pseudomonas aeruginosa: is a saprophytic bacteria in soil, water and plants, in addition to its apart of the normal flora in animals and human (4). In animals, it causes mastitis, metritis, pneumonia, dermatitis and enteritis (1).

Pseudomonas aeruginosa possess many virulence factors including: Protease: its two types: Elastase and Alkaline protease; that causes tissue necrosis, distraction of immunoglobulin and inhibition of tumor necrosis factors and gamma interferon (5). Ureases: its play a role in urea hydrolysis and ammonia releasing; these events which lead to increase of urine $\mathrm{pH}$ (6). Lipases and phospholipases: distraction of lipids surfactant and phospholipids of host cell membranes (7). Haemolysin: play role in pulmonary infection, its involved two types: Heat-labile (Phospholipase C) and Heat-stable (Glycolipid) (8). Motility : Pseudomonas aeruginosa motile by single polar flagellum, the bacterium can adhere to host epithelial cells through the binding of its flagellum to the asialyated glycolipid (9). Pigments: its causes host oxidative stress, damage of host catalase enzyme and mitochondrial electron transport (10). Also so it apple to cause inhibition of chemokine production and intra-phagocytic killing (11). Outer membrane proteins of Pseudomonas aeruginosa $(O p r I$ and $O p r L)$ : play important roles in the interaction of the bacterium with the environment as well as the its inherent resistance to antibiotics, where the consequence of the presence of these specific outer membrane proteins that have been implicated in efflux transport systems that affect cell permeability (12). As these proteins are found only in this organism, they could be a reliable factor for rapid identification of Pseudomonas aeruginosa in clinical samples (13). Exoenzyme S: encoded by the exoS gene, is an ADP ribosyltransferase that is secreted by a type-III secretion system directly into the cytosol of epithelial cells (14).

\section{Materials and methods}

This study was designed in Salahaldeen province on animals with different age, sex and species in period extended from February to May 2017. The samples were collected and transported immediately for bacterial culturing then molecular technique done in Tikrit university, laboratory of Veterinary Medicine College.

\section{Samples}

Skin scraps, swabs from wound and ear, and samples from digestive system and milk were collected. The species of animals and number of samples as in table 1 .

\section{Bacterial isolation}

it was performed by using (Pseudomonas agar base Himedia), with nalidixic acid (500 mg dissolved in $100 \mathrm{ml}$ of distilled water then add of $3 \mathrm{ml}$ of suspension to each $1 \mathrm{~L}$ of medium) and tetrazolium bromide (3g dissolved in 100 $\mathrm{ml}$, then add of $10 \mathrm{ml}$ of suspension to each $1 \mathrm{~L}$ of medium) (1).

\section{Biochemical tests which include}

Oxidase test, catalase test, Urease test, nitrate reduction test, $\mathrm{H} 2 \mathrm{~S}$ production test, Lysine decarboxylase test, indole test and Oxidation -fermentation test (1).

Table 1: species of animals and number of samples

\begin{tabular}{lcccccc}
\hline $\begin{array}{l}\text { Animals } \\
\text { species }\end{array}$ & Skin infection & Wound infection & Ear infection & $\begin{array}{c}\text { Digestive system } \\
\text { infection }\end{array}$ & $\begin{array}{c}\text { Milk samples } \\
\text { (mastitis milk) }\end{array}$ & Totals \\
\hline Dogs & 4 & 3 & 8 & 12 & 0 & 27 \\
Sheep & 2 & 15 & 2 & 5 & 4 & 28 \\
Goat & 3 & 11 & 3 & 1 & 7 & 25 \\
Cow & 1 & 3 & 6 & 4 & 8 & 22 \\
Hours & 3 & 3 & 8 & 4 & 0 & 18 \\
\hline Total & 13 & 35 & 27 & 26 & 19 & 120 \\
\hline
\end{tabular}




\section{Serotyping}

By used monoclonal antibodies (Sanofi Diagnostics Pasteur- France) which are anti O- poly saccharide (1P$16 \mathrm{p}$ ). appearance of agglutination between bacteria and monoclonal antibodies refer to its serotype.

\section{Detection of virulence factors}

Capsule detection: by using of Indian ink, Motility activity detected by used of Triple Sugar Iron sugar iron and according to (15). Production of amylase enzyme detected by using of Starch medium and according to (16). Production of hemolysin enzyme detected by using of blood agar. Production of protease enzyme detected by using of skim milk agar and according to (17). Production of phospholipase enzyme detected by using of nutrient agar, Nacl and egg yolk and according to (18). Production of Urease enzyme detected by using of urea media Production of DNAase detected by using of DNA media. Gelatin liquefaction test: by used of gelatin media and according to (15). Detection of $\beta$-lactamase production applied according to (19).

\section{DNA extraction}

For genetic methods performed by reactivation of Pseudomonas aeruginosa by culturing in trypton soya agar at $37 \mathrm{c}$ for 24 hours. and bacterial DNA extracted according to methods describe by (20). And by using of Genomic DNA Mini Kit (blood/cultured cell) (Geneaid).
(C\#:GB100/300) primers used in current study: these primers were chosen depending on (21) as table 2 .

\section{Compounds used in preparation of reaction mixture}

The component that used in genetic included: Taq PCR Master Mix KIT $(20 \mu \mathrm{l})$, Forward primer $(1.4 \mu \mathrm{l})$, Reverse primer $(1.4 \mu \mathrm{l})$, DNA Template $(2 \mu \mathrm{l})$ and DNA free water $(15.2 \mu 1)$.

\section{Thermocycler programs}

Thermocycler were set in three steps: First Denaturation step with $95^{\circ} \mathrm{C}$ for 5 mints, Denaturation step with $95^{\circ} \mathrm{C}$ for 30 second, DNA extension step with $72^{\circ} \mathrm{C}$ for 30 seconds and Primer-annealing step with $55^{\circ} \mathrm{C}, 58^{\circ} \mathrm{C}, 60^{\circ} \mathrm{C}$ and $55^{\circ} \mathrm{C}$ for 30 seconds for, oprI, oprL and exoT respectively.

\section{Results}

The current study showed difference in isolation rate of Pseudomonas aeruginosa according type of samples, the highest isolation rate was recorded in milk and ear samples which are $26.8 \%$ and $25.9 \%$ respectively and lowest isolation rate in wound infection (11.4\%).

The isolation rate differs according to species of animals the higher infection rate recorded in doges was $29.6 \%$. and lowest rate recorded in horses $(16.6 \%)$. Table 3 describe the infection rate in different samples for each animals spp.

Table 2: primers used in study

\begin{tabular}{|c|c|c|c|}
\hline Gene name & Gene text & product size & Company \\
\hline oprI & F 5'CGGCTGGGAGATTGCTGTTA3' & $202 \mathrm{pb}$ & (BioRad, USA) \\
\hline & $\begin{array}{l}\text { 5'-CCTT GCGATAGGCTTCGTCA3' } \\
\text { 5' } G G A A T G A A C G A A G C G T T C T C{ }^{2},\end{array}$ & & \\
\hline oprL & $\begin{array}{l}\mathrm{F} \\
\mathrm{R} \\
\mathrm{R}\end{array}$ & $300 \mathrm{bp}$ & (BioRad, USA) \\
\hline exoT & $\begin{array}{ll}\mathrm{F} & \text { 5'-AATCGCCGTCCAACTGCATGCG-3' } \\
\mathrm{R} & 5 \text { '-TGTTCGCCAGAGGTACTGCTC-3' }\end{array}$ & $150 \mathrm{bp}$ & Alpha DNA, Canada \\
\hline exos & $\begin{array}{ll}\mathrm{F} & 5, C T T \text { GAA GGG ACT CGA CAA GG 3, } \\
\mathrm{R} & \text { 5' TTC AGG TCC GCG TAG TGA AT 3, }\end{array}$ & 504 bp & (BioRad, USA) \\
\hline
\end{tabular}

Table 3: Pseudomonas aeruginosa infection ratio in different animals and simples

\begin{tabular}{|c|c|c|c|c|c|c|c|c|c|c|c|c|}
\hline \multirow{3}{*}{ Animals } & \multicolumn{12}{|c|}{ Samples } \\
\hline & \multicolumn{2}{|c|}{$\begin{array}{c}\text { Skin } \\
\text { infection }\end{array}$} & \multicolumn{2}{|c|}{$\begin{array}{l}\text { Wound } \\
\text { infection }\end{array}$} & \multicolumn{2}{|c|}{$\begin{array}{c}\text { Ear } \\
\text { infection }\end{array}$} & \multicolumn{2}{|c|}{$\begin{array}{c}\text { Digestive } \\
\text { system infection }\end{array}$} & \multicolumn{2}{|c|}{$\begin{array}{c}\text { Milk samples } \\
\text { (mastitis milk) }\end{array}$} & \multicolumn{2}{|r|}{ Totals } \\
\hline & No. & $\begin{array}{c}\text { Infection } \\
\text { No. and \% }\end{array}$ & No. & $\begin{array}{c}\text { Infection } \\
\text { No. and \% }\end{array}$ & No. & $\begin{array}{c}\text { Infection } \\
\text { No. and \% }\end{array}$ & No. & $\begin{array}{c}\text { Infectio } \\
\text { No. and \% }\end{array}$ & No. & $\begin{array}{c}\text { Infection } \\
\text { No. and \% }\end{array}$ & No. & $\begin{array}{c}\text { Infection } \\
\text { No. and \% }\end{array}$ \\
\hline Doges & 4 & $1(25.0 \%)$ & 3 & $0(0.0 \%)$ & 8 & $5(62.5 \%)$ & 12 & $2(16.66)$ & 0 & $0(0.0 \%)$ & 27 & $8(29.6)$ \\
\hline Sheep & 2 & $0(0.0 \%)$ & 15 & $3(20 \%)$ & 2 & $0(0.0 \%)$ & 5 & $1(20.0 \%)$ & 4 & $1(25.0 \%)$ & 28 & $5(17.8 \%)$ \\
\hline Goats & 3 & $1(33.3 \%)$ & 11 & $1(9.0 \%)$ & 3 & $1(33.3 \%)$ & 1 & $0(0.0 \%)$ & 7 & $3(42.8 \%)$ & 25 & $6(24 \%)$ \\
\hline Cows & 1 & $0(0.0 \%)$ & 3 & $0(0.0 \%)$ & 6 & $0(0.0 \%)$ & 4 & $1(25.0 \%)$ & 8 & $3(37.5 \%)$ & 22 & $4(18.1 \%)$ \\
\hline Horse & 3 & $0(0.0 \%)$ & 3 & $0(0.0 \%)$ & 8 & $1(12.5 \%)$ & 4 & $2(50.0 \%)$ & 0 & $0(0.0 \%)$ & 18 & $3(16.6 \%)$ \\
\hline Total & 13 & $2(15.38)$ & 35 & $4(11.4 \%)$ & 27 & $7(25.9 \%)$ & 26 & $6(23.0 \%)$ & 19 & $7(26.8 \%)$ & 120 & $26(12.6 \%)$ \\
\hline
\end{tabular}




\section{Serotyping of Pseudomonas aeruginosa:}

Table 4 shows serotypes of Pseudomonas aeruginosa that isolated in current study.

Table 4: Serotype of $P$. aeruginosa isolated from different animal

\begin{tabular}{lcc}
\hline Serotypes & No. of samples & Rate \\
\hline O3 & 3 & $11.5 \%$ \\
O6 & 5 & $19.2 \%$ \\
O9 & 17 & $65.38 \%$ \\
O11 & 1 & $3.8 \%$ \\
\hline Total & 26 & $100 \%$ \\
\hline
\end{tabular}

\section{Virulence factors}

The ratio of virulence factors were capsule: $19.2 \%$, motility $100 \%$, amylase enzyme: $100 \%$, hemolysin enzyme: $61.5 \%$, protase: $30 \%$, phospholipase enzyme: $34.6 \%$, urease enzyme: $19.2 \%$, DNAase: $0 \%$, gelatin 1 liquefaction test: $92.3 \%$, B-lactamase production: $61.5 \%$, Pigments: $88.4 \%$. Table 5 showed virulence factors of $p$. aeruginosa isolated from different animal samples.

\section{Genetic methods used in detection of virulence factors}

The $O p r I$ and exoT genes were detected in about $88 \%$ of pseudomonas isolates, exoS gene detected in $76.9 \%$ while OprL detected in $69.2 \%$ from total number of pseudomonas isolates, as in table 6 and figure 1-4 shows result of PCR test.

Table 5: Virulence factors of $P$. aeruginosa isolated from different animal samples

\begin{tabular}{|c|c|c|c|c|c|c|c|c|c|c|c|c|}
\hline \multirow{3}{*}{ Virulence factors } & \multicolumn{12}{|c|}{ Samples types } \\
\hline & \multicolumn{2}{|c|}{$\begin{array}{c}\text { Skin } \\
\text { infection } \\
(2)\end{array}$} & \multicolumn{2}{|c|}{$\begin{array}{c}\text { Wound } \\
\text { infection } \\
(4)\end{array}$} & \multicolumn{2}{|c|}{$\begin{array}{c}\text { Ear infection } \\
(7)\end{array}$} & \multicolumn{2}{|c|}{$\begin{array}{l}\text { Digestive } \\
\text { system } \\
\text { infection (6) }\end{array}$} & \multicolumn{2}{|c|}{$\begin{array}{l}\text { Milk samples } \\
\text { (mastitis } \\
\text { milk) (7) }\end{array}$} & \multicolumn{2}{|c|}{$\begin{array}{l}\text { Totals } \\
(26)\end{array}$} \\
\hline & No & $\%$ & No & $\%$ & No & $\%$ & No & $\%$ & No & $\%$ & No & $\%$ \\
\hline Capsule & 1 & $50 \%$ & 0 & $0 \%$ & 2 & $28.5 \%$ & 1 & $16.6 \%$ & 2 & $28.5 \%$ & 5 & $19.2 \%$ \\
\hline Motility & 2 & $100 \%$ & 4 & $100 \%$ & 7 & $100 \%$ & 4 & $\%$ & 7 & $100 \%$ & 26 & $100 \%$ \\
\hline amylase enzyme & 0 & $0 \%$ & 0 & $0 \%$ & 0 & $0 \%$ & 0 & $0 \%$ & 1 & $14.2 \%$ & 1 & $3.8 \%$ \\
\hline hemolysin enzyme & 1 & $50 \%$ & 3 & $75 \%$ & 4 & $57.1 \%$ & 4 & $66.6 \%$ & 4 & $57.1 \%$ & 16 & $61.5 \%$ \\
\hline Protase & 2 & $100 \%$ & 1 & $25 \%$ & 2 & $28.5 \%$ & 1 & $16.6 \%$ & 2 & $28.5 \%$ & 8 & $30 \%$ \\
\hline phospholipase enzyme & 1 & 50 & 1 & $25 \%$ & 2 & $28.5 \%$ & 1 & $16.6 \%$ & 4 & $56.1 \%$ & 9 & $34.6 \%$ \\
\hline Urease enzyme & 1 & $50 \%$ & 0 & $0 \%$ & 1 & $14.2 \%$ & 2 & $33.3 \%$ & 1 & $14.2 \%$ & 5 & $19.2 \%$ \\
\hline DNAase & 0 & $0 \%$ & 0 & $0 \%$ & 0 & $0 \%$ & 0 & $0 \%$ & 0 & $0 \%$ & 0 & $0 \%$ \\
\hline Gelatin 1 liquefaction test & 2 & $100 \%$ & 3 & $75 \%$ & 7 & $100 \%$ & 5 & $83.3 \%$ & 7 & $100 \%$ & 24 & $92.3 \%$ \\
\hline$\beta$-lactamase production & 2 & $100 \%$ & 4 & $100 \%$ & 5 & $71.4 \%$ & 4 & $66.6 \%$ & 3 & $42.8 \%$ & 16 & $61.5 \%$ \\
\hline Pigments & 2 & $100 \%$ & 3 & $75 \%$ & 7 & $100 \%$ & 5 & $83.3 \%$ & 6 & 85.7 & 23 & $88.4 \%$ \\
\hline
\end{tabular}

Table 6: virulence factors of Pseudomonas aeruginosa isolated from different animal samples

\begin{tabular}{|c|c|c|c|c|c|c|c|c|c|c|c|c|}
\hline \multirow{3}{*}{$\begin{array}{l}\text { Virulence } \\
\text { factors }\end{array}$} & \multicolumn{12}{|c|}{ Samples } \\
\hline & \multicolumn{2}{|c|}{$\begin{array}{c}\text { Skin } \\
\text { infection (2) }\end{array}$} & \multicolumn{2}{|c|}{$\begin{array}{c}\text { Wound } \\
\text { infection (4) }\end{array}$} & \multicolumn{2}{|c|}{$\begin{array}{c}\text { Ear infection } \\
(7)\end{array}$} & \multicolumn{2}{|c|}{$\begin{array}{l}\text { Digestive system } \\
\text { infection (6) }\end{array}$} & \multicolumn{2}{|c|}{$\begin{array}{c}\text { Milk samples } \\
\text { (mastitis milk) (7) }\end{array}$} & \multicolumn{2}{|c|}{$\begin{array}{l}\text { Totals } \\
\text { (26) }\end{array}$} \\
\hline & No & $\%$ & No & $\%$ & No & $\%$ & No & $\%$ & No & $\%$ & No & $\%$ \\
\hline oprI & 2 & $100 \%$ & 4 & $100 \%$ & 7 & 100 & 4 & $66.6 \%$ & 5 & $71.4 \%$ & 23 & $88.4 \%$ \\
\hline oprL & 2 & $100 \%$ & 4 & $100 \%$ & 6 & $85.7 \%$ & 4 & $66.6 \%$ & 2 & $28.5 \%$ & 18 & $69.2 \%$ \\
\hline ExoT & 2 & $100 \%$ & 4 & $100 \%$ & 4 & $57.1 \%$ & 5 & $83.3 \%$ & 6 & $85.7 \%$ & 23 & $88.46 \%$ \\
\hline $\operatorname{exo} S$ & 2 & $100 \%$ & 3 & $75 \%$ & 6 & $85.7 \%$ & 3 & $50 \%$ & 6 & $85.7 \%$ & 20 & $76.9 \%$ \\
\hline
\end{tabular}

\section{Discussion}

In this study, $P$. aeruginosa isolated from all animal samples with different levels. This result was in agreement with the study of AL-hadithi (22) who isolated $P$. aeruginosa from different animal samples in Baghdad. The highest isolation rate was recorded in samples of dogs ear and this was in agreement with Doge et al. (23).

$P$. aeruginosa can causes otitis externa in canines it cause inflammation and ulceration within the external ear canal (13). 


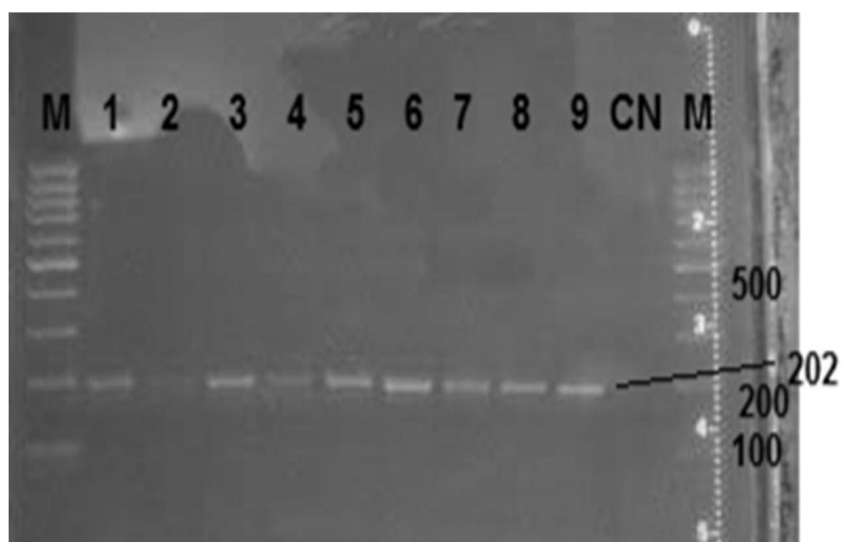

Figure 1: Agarose gel electrophoresis of PCR products. M: $100 \mathrm{bp}$ DNA ladder, lines (1-8) positive result at $202 \mathrm{bp}$ for oprI, of $P$. aeruginosa.

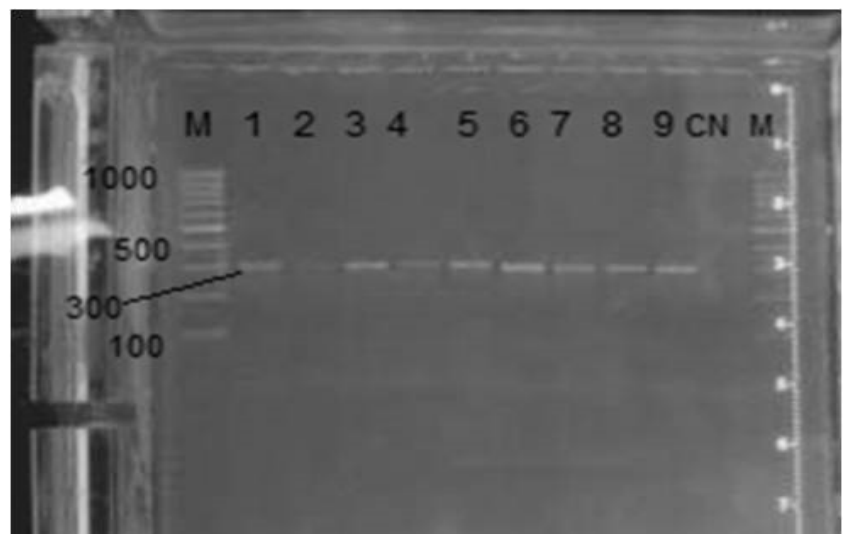

Figure 2: Agarose gel electrophoresis of PCR products. M: $100 \mathrm{bp}$ DNA ladder, lines (1-8) positive result at $300 \mathrm{bp}$ for oprL, of $P$. aeruginosa.

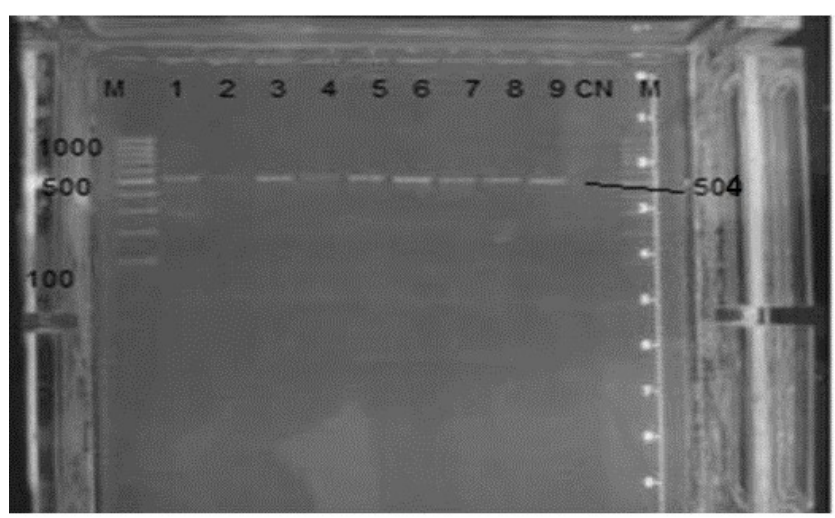

Figure 3: Agarose gel electrophoresis of PCR products. M: 100 bp DNA ladder, lines (1-8) positive result at 505 bp for exoS, of $P$. aeruginosa.

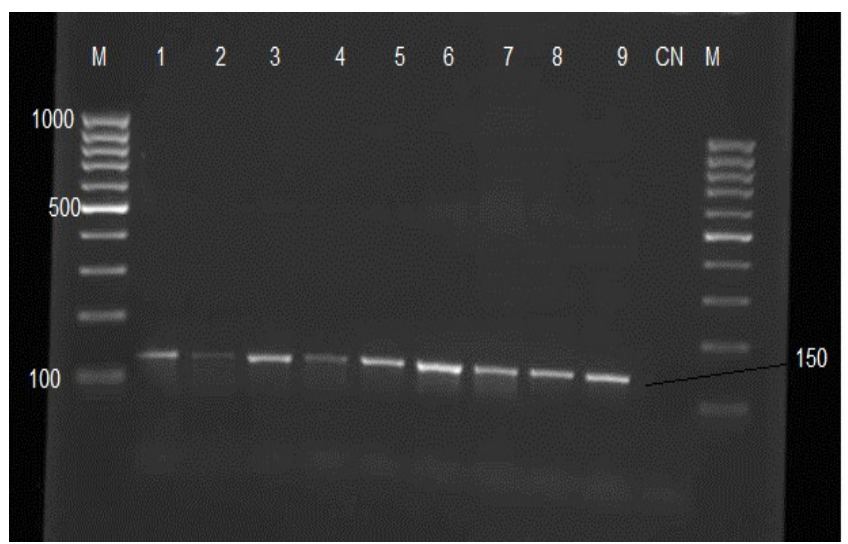

Figure 4: Agarose gel electrophoresis of PCR products. M: $100 \mathrm{bp}$ DNA ladder, lines (1-8) positive result at 150bp for ExoT, of $P$. aeruginosa.

The isolation of $P$. aeruginosa from milk in the current study, may be referred to either ability of $P$. aeruginosa to live in wide range of temperature or its one the causes of mastitis also might be due to contamination after milking.

The present study also showed difference in the serotyping of the isolation. The dominance of one serotype in compare with others may be due to geographic distribution, resistance to host immunity and environmental prevalence, and antibiotics resistances $(23,24)$.

Some isolates appeared to have capsule. This result differ from result recorded by Al-Mashhadani (25) were $0 \%$, and result recorded by AL-Salihi and Hasan (26) were $42.8 \%$, that's may be due to different in type of infection. Capsule play important role in prevention of phagocytosis so that its protect bacteria from anther types of immunological invasion (27).

Hemolysin enzyme detection in $61.5 \%$, that agreement with (25). Hemolysin associated with necrotoxicity and cytotoxicity of the cells. It can form pores in the erythrocytes plasma membrane (28). All isolates were motile, DNAase negative, this agreement with (25). Most isolate were positive to pigments production and gelatin liquefaction. and that's was agreement with (25). Pigments play important role in pathogenicity of $P$. aeruginosa and reduce of host immunity $(10,11)$.

Ureases enzyme detected in $19.2 \%$ of total isolates, this enzyme able to distract urea into $\mathrm{CO}_{2}$ and $\mathrm{NH}_{3}$ and increase $\mathrm{pH}$ which enhance bacterial growth (29).

Further more the rsults study showed many bacteria gave positive results in protease detection test. Protease enzyme enhance infection by damage of host cells and break down of immune defense mechanism like skin and mucous membranes $(29,30)$. 
In current study extracellular toxin (exoS and exoT) were detected in most isolates. The extracellular toxin can causes necrosis, edema and hemorrhage (14).

The outer membrane proteins OprI and OprL were detected in different rate according to isolate source. The outer membrane proteins effect in cellular permeability and increase antibiotic resistance (14).

\section{References}

1. Quinn PJ, Carter ME, Markey B, Carter GR. Clinical Vet Microbiol. Mosby Pub Co. 1998;pp:237-242.

2. Collee JG, Marr W. Culture of Bacteria. In Macki and McCarthy practical medical microbiology. $14^{\text {th }}$ Ed. Collee, J.G.; Fraser, A.G.; Marmion, B.P. and Simmons, A. Churchill Livingstone. 1996; pp:117118.

3. Murray PR, Baron EJ, Jorgensen JH, Pfaller MA, Yolken RH. Manual of clinical microbiology. American Society for Microbiology, Washington, DC. 2003:pp.517-524

4. Chakraborty P. A Textbook of Microbiology. Pseudomonas Graphitech. India. Limited. 1996.

5. Pollack M. Pseudomonas aeruginosa. In.: Principles and Practice of Infectious Diseases, by: Mandel GL, Bennett JE. Churchill Livingstone, New York. 1995; pp:1980-2003.

6. Aouf A. Bacteriological and enzymatic study of Pseudomonas aeruginosa producing Elastase. M.Sc. Thesis, Biology/ Microbiology, College of Science, Baghdad University. 2001.

7. Kipnis E, Sawa T, Wiener-Kronish J. Targeting mechanisms of Pseudomonas aeruginosa pathogenesis. Med Mal Infect. 2006;36:7891.

8. Brooks GF, Butel JS, Morse SA. Pseudomonas, acentabacters and uncommon G-ve bacteria. In: Jawetz, Meluick and Adelberg's Medical Microbiology, Typo. Press, Lebanon. 1998;pp:231-236.

9. Branson D. "Methods in clinical bacteriology manual oftests and procedures". Springfield. Illinois. USA. 1972.

10. Lau GW, Hassett DJ, Ran H, Kong, F. The role of pyocyanin in Pseudomonas aeruginosa infection. Trends Mol Med. 2004; 10:599606.

11. Vinckx T, Wei Q, Matthijs S, Cornelis P. The Pseudomonas aeruginosa oxidative stress regulator OxyR influences production of pyocyanin and rhamnolipids: protective role of pyocyanin. Microbiol. 2010;156:678-686.

12. Nikaido H. Prevention of drug access to bacterial targets: Permeability barriers and active efflux. Science.1994;264:382-388.

13. Davis BD, Dulbecco R, Eisen HN, Ginsberg HS. Microbio-logy. 4th Ed. Harper and Row Publishers, Inc. 1990.

14. Anthonv WM, Qing D, Michael SP, Bassam TW. Joseph, TB. Pseudomonas aeruginosa exoS ADP-ribosyltransferase inhibits ERM phosphorylation. Cellular Microbiol. 2007;9(1):97-105.
15. Cruickshank R, Duguid JP, Marmoin BP, Swain RH. Pseudomonas; Loefflerella. In: Medical Microbiology. The Practice of Medical Microbiology, 12th Ed. Vol. II, Churchill Livingstone, New York. 1975;pp: 444-447.

16. MacFaddin JF. Biochemical tests for identification of medical bacteria. 3rd ed. Lippincott Williams \& Wilkins, Philadelphia. 2000:pp.424-438.

17. Benson CA, Deeks SG, Brun SC, Gulick RM, Eron JJ, Kessler HA Feinberg J. Safety and antiviral activity at 48 weeks of lopinavir/ritonavir plus nevirapine and 2 nucleoside reversetranscriptase inhibitors in human immunodeficiency virus type 1infected protease inhibitor-experienced patients. J Infectious Dis. 2002;185(5):599-607.

18. Atlas RM. Principles of Microbiology, 1st Ed. Mosby, Inc. Missouri. 1995;pp:364.

19. Lee WS, Komarmy LOUIS. Iodometric spot test for detection of betalactamase in Haemophilus influenzae. J Clin Microbiol. 1981;13(1):224-225.

20. Nikbin VS, Aslani MM, Sharafi Z, Hashemipour M, Shahcheraghi F, Ebrahimipour GH. Molecular identification and detection of virulence genes among Pseudomonas aeruginosa isolated from different infectious origins. Iranian J Microbiol. 2012;4(3):118.

21. Khattab MA, Nour MS. ElSheshtawy NM. Genetic identification of Pseudomonas aeruginosa virulence genes among different isolates. J Microb Biochem Technol. 2015;7:274-277.

22. Al-Hadithi ABA. Isolation and Identification of Pseudomonas aeruginosa from Human and Animal. Master thesis. Bagdad university-collage of vet. Medicine. 2007.

23. Degi J, Cristina RT, Stancu, A. Otitis externa caused by bacteria of the genus Pseudomonas in dogs. J Lucrari Stiintifice Medicina Veterinara. 2010;63(1):410-415.

24. Miller WH. Griffin CE, Campbell KL. Diseases of eyelids, Claws, Anal Sacs, and Ears. In: Miller WH, Griffin CE, Campbell KL. Small Animal Dermatology 7th Ed. St Louis: Elsevier Mosby. 2013;pp:741767.

25. Al-Mashhadani KA. A Study on Diagnosis and Pathogenesis of Pseudomonas aeruginosa Isolated from Different Sources In Mosul City. Ph. D. Thesis. Mosul University- College of Science. 2004.

26. AL-Salihi SS, Hasan AA. Detection of some virulence factors in Pseudomonas aeruginosa associated with diarrhea in Kirkuk City. KUJSS. 2015;10(1):78-89.

27. Sridhar Rao PN. Anatomy of bacteria cell. JMMC Dvangere Chapter 3.3.21, 2009.

28. Linggood AM, Ingram PL. The role of alpha-hemolysin in the virulence of $E$. coli for mice. J Med Microbial. 2008;14:439-450.

29. Nile HR, Hassan LA, Jabber EY. Virulence Factors of Pseudomonas aeruginosa Isolated from Wound and Burn Infections. IJCRBP. 2015;2(6):153-162.

30. Sabharwal N, Dhall S, Chhibber S, Harjai K. Molecular detection of virulence genes as markers in Pseudomonas aeruginosa isolated from urinary tract infections. IJMEG, 2014;5(3):125. 